\title{
GAMBARAN STATUS KARIES PADA MURID SMP NEGERI 4 TOULUAAN KECAMATAN SILIAN RAYA KABUPATEN MINAHASA TENGGARA
}

\author{
${ }^{1}$ Billy O. S. Mayusip \\ ${ }^{2} \mathrm{Ni}$ Wayan Mariati \\ ${ }^{2}$ Christy N. Mintjelungan
}

\author{
${ }^{1}$ Kandidat Skripsi Program Studi Pendidikan Dokter Gigi Fakultas Kedokteran \\ ${ }^{2}$ Program Studi Pendidikan Dokter Gigi Fakultas Kedokteran \\ Universitas Sam Ratulangi \\ Email: billysamuel@windowslive.com
}

\begin{abstract}
Caries is a dental hard tissue disease, which involves enamel, dentin, and cementum. It is caused by a microorganism activity inside carbohydrates that can be fermented. Dental caries widely occurs among school aged children since they often consume meal that potentially can cause caries. SMP Negeri 4 Touluaan is a junior high school located in kecamatan Silian Raya. This study aimed to obtain the dental caries status of students at SMP Negeri 4 Touluaan. This was a descriptive study with a cross-sectional approach. The population consisted of 240 students. Samples were 71 students obtained by using Slovin's formula and a purposive sampling method. The results showed that the average DMF-T index of SMP Negeri 4 Touluaan students was 3.52, that belonged to the medium or fair category based on the WHO criteria.
\end{abstract}

Keywords: caries status, junior high school students, DMF-T Index

\begin{abstract}
Abstrak: Karies merupakan suatu penyakit jaringan keras gigi, yaitu email, dentin dan sementum, yang disebabkan oleh aktivitas jasad renik dalam karbohidrat yang dapat diragikan. Penyakit ini banyak terjadi pada anak usia sekolah. Anak-anak sekolah seringkali mengonsumsi makanan dengan kandungan substrat yang berpotensi menyebabkan karies. SMP Negeri 4 Touluaan merupakan SMP yang terletak di kecamatan Silian Raya. Penelitian ini bertujuan untuk mengetahui gambaran status karies pada murid SMP Negeri 4 Touluaan. Penelitian ini merupakan penelitian deskriptif dengan pendekatan potong lintang. Populasi total sebanyak 240 siswa. Sampel penelitian didapat menggunakan rumus Slovin yaitu sebanyak 71 siswa. Pengambilan sampel menggunakan purposive sampling. Hasil penelitian ini menunjukan indeks DMF-T rata-rata pada siswa SMP Negeri 4 Touluaan sebesar 3,52 yang tergolong dalam kategori sedang menurut kriteria DMF-T yang dikeluarkan WHO.

Kata kunci: status karies, murid sekolah menengah pertama, indeks DMF-T
\end{abstract}

Kesehatan gigi dan mulut merupakan salah satu hal yang penting dalam kehidupan manusia. Masalah kesehatan gigi dan mulut masih perlu diperhatikan, karena pernyakit gigi dan mulut masih menjadi masalah yang sering dikeluhkan oleh masyarakat. Salah satu penyakit gigi dan mulut yang banyak diderita masyarakat terutama pada anak-anak ialah karies gigi. Karies merupakan suatu penyakit jaringan keras gigi, yaitu email, dentin dan sementum, yang disebabkan oleh suatu aktivitas jasad renik dalam suatu karbohidrat yang dapat diragikan. Tandanya yaitu demineralisasi jaringan keras gigi yang kemudian diikuti oleh kerusakan bahan organiknya. 
Akibatnya terjadi invasi bakteri dan kematian pulpa serta penyebaran infeksinya ke jaringan periapeks yang menyebabkan nyeri. Walaupun demikian mengingat mungkinnya remineralisasi terjadi, pada stadium sangat dini penyakit ini dapat dihentikan. ${ }^{1}$ Penyakit karies gigi banyak terjadi pada anak usia sekolah. Usia sekolah ialah masa untuk meletakkan landasan kokoh bagi terwujudnya manusia berkualitas dan kesehatan merupakan faktor penting yang menentukan kualitas sumber daya manusia.Karies pada anak sekolah cenderung disebabkan karena pola makan anak-anak yang tidak terkontrol. Anak-anak sekolah seringkali mengonsumsi makanan dengan kandungan substrat yang berpotensi menyebabkan karies. Oleh sebab itu anak usia sekolah merupakan kelompok yang tergolong rentan terhadap gangguan kesehatan gigi dan mulut., ${ }^{2,3}$ Menurut World Health Organization (WHO), usia 12 tahun merupakan usia pemantauan global untuk karies serta diperkirakan semua gigi permanen telah erupsi, terkecuali gigi molar tiga. Kelompok usia 12 tahun merupakan indikator kritis, karena sekitar 76,97\% karies menyerang pada usia tersebut. Kelompok usia 12 tahun juga merupakan kelompok yang mudah dijangkau oleh Usaha Kesehatan Gigi Sekolah (UKGS), sehingga usia 12 tahun ditetapkan sebagai usia pemantauan global untuk karies gigi., ${ }^{4,5}$

Berdasarkan Riset Kesehatan Dasar (RISKESDAS) tahun 2013, indeks DMF-T (Decayed, Missing, Filling - Teeth) di Indonesia sebesar 4,6 yang berarti kerusakan gigi penduduk Indonesia 460 gigi per 100 orang dan termasuk dalam kategori tinggi. Indeks DMF-T pada lakilaki sebesar 4,1 termasuk kategori sedang, dan pada perempuan sebesar 4,9 termasuk kategori tinggi. Indeks DMF-T provinsi Sulawesi Utara adalah 5,4 yang termasuk dalam kategori tinggi. ${ }^{6}$ SMP Negeri 4 Touluaan, merupakan sekolah menengah pertama yang terletak di kecamatan Silian Raya. Letak kecamatan Silian Raya sendiri berada kurang lebih 8 kilometer dari kaki
Gunung Soputan Minahasa Tenggara. Menurut survei awal yang dilakukan oleh peneliti, sekolah ini belum memiliki sarana dan prasarana yang memadai misalnya sarana UKGS, dan juga sekolah ini belum pernah mendapatkan penyuluhan kesehatan gigi dan mulut. Berdasarkan hal-hal tersebut diatas, peneliti tertarik untuk melakukan penelitian tentang suatu masalah yaitu gambaran status karies pada anak SMP Negeri 4 Touluaan, kecamatan Silian Raya kabupaten Minahasa Tenggara.

\section{METODE PENELITIAN}

Penelitian ini merupakan penelitian deskriptif dengan menggunakan desain potong lintang (cross-sectional). Penelitian bertempat di SMP Negeri 4 Touluaan kecamatan Silian Raya kabupaten Minahasa Tenggara. Populasi pada penelitian ini yaitu seluruh siswa SMP usia 12-14 tahun, di SMP Negeri 4 Touluaan yang berjumlah 240 orang. penelitian ini menggunakan metode purposive sampling, besar sampel diperoleh menggunakan rumus Slovin dan didapatkan hasil sebesar 70,58 yang kemudian dibulatkan menjadi 71 responden. Penelitian dilakukan pada sampel yang sesuai dengan kriteria inklusi dan eksklusi. Dilakukan pemeriksaan dengan menggunakan alat diagnostik untuk mendapatkan data tentang status karies berdasarkan indeks DMF-T. Sebelum melakukan penelitian, peneliti terlebih dahulu memberikan informed concent pada orang tua/ wali dari anak yang akan diteliti, dan memberikan informasi mengenai maksud dan tujuan dilakukannya penelitian ini. Setelah informed concent yang dibagikan telah disetujui oleh orang tua/ wali, pemeriksaan dilakukan dengan menggunakan alat diagnostik untuk mendapatkan data tentang status karies gigi melalui indeks DMF-T. Untuk membantu peneliti pada saat penelitian dibentuk tim kerja yang terdiri dari tiga orang yang merupakan mahasiswa S1 dari program studi pendidikan dokter gigi yang terlebih dahulu sudah diberikan materi tentang pemeriksaan status karies menggunakan 
indeks DMF-T yang dikeluarkan oleh WHO. ${ }^{7}$ (Tabel 1)

Tabel 1. Kategori Perhitungan DMF-T Menurut WHO. ${ }^{7}$

\begin{tabular}{cc}
\hline Kategori & DMF-T \\
\hline Sangat Rendah & $0,0-1,1$ \\
Rendah & $1,2-2,6$ \\
Sedang & $2,7-4,4$ \\
Tinggi & $4,5-6,5$ \\
Sangat Tinggi & $>6,6$ \\
\hline
\end{tabular}

Alat yang digunakan pada penelitian disterilkan dengan cara direndam dalam larutan iodin yang telah disediakan, lalu dibilas dengan air bersih, Setelah dibilas dengan air bersih, alat kemudian direndam ke dalam alkohol yang telah disediakan. Setelah alat direndam dengan alkohol, alat terlebih dahulu harus dikeringkan dengan tissue yang telah disediakan sebelum digunakan pada responden. Data diolah berdasarkan persentase yang disajikan dalam bentuk table frekuensi untuk melihat status karies responden.

\section{HASIL PENELITIAN}

Terdapat 71 siswa dan siswi yang menjadi responden dalam penelitian ini dengan persentase jumlah siswa 54,93\% dan siswi 45,07\%. (Tabel 2)

Tabel 2. Distribusi karakteristik responden berdasarkan jenis kelamin

\begin{tabular}{ccc}
\hline $\begin{array}{c}\text { Jenis } \\
\text { Kelamin }\end{array}$ & Jumlah & $(\%)$ \\
\hline Laki-laki & 39 & 54,93 \\
Perempuan & 32 & 45,07 \\
\hline Jumlah & 71 & 100 \\
\hline
\end{tabular}

Terdapat tiga kategori usia dalam penelitian ini yaitu usia 12 tahun (28,17\%), usia 13 tahun (33,80\%) dan 14 tahun (38,03\%). (Tabel 3)

Tabel 3. Distribusi karakteristik responden berdasarkan usia

\begin{tabular}{ccc}
\hline Usia & Jumlah & $(\%)$ \\
\hline 12 & 20 & 28,17 \\
\hline
\end{tabular}

\begin{tabular}{ccc}
\hline 13 & 24 & 33,80 \\
14 & 27 & 38,03 \\
\hline Jumlah & 71 & 100 \\
\hline
\end{tabular}

Dari hasil pemeriksaan DMF-T pada siswa SMP Negeri 4 Touluaan, jumlah indeks D (decayed) berjumlah 214, M (missing) berjumlah 36, sedangkan F (filling) tidak ada. Indeks DMF-T rata-rata yang di dapat dari 71 responden di SMP Negeri 4 Touluan sebesar 3,52. Berdasarkan kriteria WHO, indeks ini berada pada kategori karies sedang (Tabel 4).

Tabel 4. Distribusi status karies berdasarkan jenis kelamin

\begin{tabular}{cccccc}
\hline $\begin{array}{c}\text { Jenis } \\
\text { Kelamin }\end{array}$ & D & M & F & Skor & Kategori \\
\hline Laki-laki & 127 & 22 & 0 & 3,82 & Sedang \\
Perempuan & 87 & 14 & 0 & 3,16 & Sedang \\
Total & 214 & 36 & 0 & & \\
\hline
\end{tabular}

Hasil menunjukkan bahwa rata-rata indeks DMF-T pada murid laki-laki lebih tinggi dibandingkan dengan murid perempuan. Hasil DMF-T berdasarkan usia menunjukan seluruh kelompok usia memiliki indeks karies yang dikategorikan sedang. Kelompok umur dengan skor tertinggi ialah kelompok umur 13 tahun dengan skor 4,08 yang tergolong dalam kategori sedang. (Tabel 5)

Tabel 5. Distribusi status karies berdasarkan usia

\begin{tabular}{cccccc}
\hline $\begin{array}{c}\text { Usia } \\
\text { (Tahun) }\end{array}$ & D & M & F & Skor & Kategori \\
\hline 12 & 53 & 9 & 0 & 3,1 & Sedang \\
13 & 89 & 9 & 0 & 4,08 & Sedang \\
14 & 72 & 18 & 0 & 3,33 & Sedang \\
Total & 214 & 36 & 0 & & \\
\hline
\end{tabular}

\section{BAHASAN}

Data hasil penelitian menunjukkan rata-rata indeks DMF-T dari 71 responden di SMP Negeri 4 Touluaan sebesar 3,52. Menurut kriteria dari World Health Organization (WHO), indeks ini berada 
pada kategori sedang. Responden yang di teliti semuanya memiliki skor filling (F) nol, karena tidak ditemukan responden yang menambal giginya. Hasil pemeriksaan DMF-T pada anak SMP Negeri 4 Touluaan dalam masing-masing indeks, yaitu D (decay) sebanyak 214, M (missing) sebanyak 36, F (filling) sebanyak 0. Hasil penelitian yang dilakukan Pontonuwu di Kinilow, Tomohon. Indeks DMF-T pada anak sekolah yang berusia 11-12 tahun yaitu D (decay) berjumlah 206, M (missing) berjumlah 48, F (filling) berjumlah 1, hampir mendekati dengan skor F (filling)yang didapatkan oleh peneliti. ${ }^{8}$ Masyarakat di daerah Sulawesi Utara lebih memilih perawatan pencabutan gigi daripada penambalan karena tingkat pengetahuan yang kurang akan kesehatan gigi dan mulut. Berdasarkan RISKESDAS 2013 angka D-F di provinsi Sulawesi Utara sebesar 0,06 yang artinya jumlah gigi yang memiliki tambalan cenderung sedikit bila dibandingkan dengan angka DMF-T yang di miliki oleh provinsi Sulawesi Utara yaitu sebesar 5,4. ${ }^{6}$ Menurut survey awal yang dilakukan peneliti kecamatan Silian Raya memiliki satu fasilitas layanan kesehatan berupa Puskesmas Silian dengan kode puskesmas P7109062101, tidak ada tenaga dokter gigi yang tersedia di puskesmas Silian Raya. ${ }^{9}$ Hal ini merupakan salah satu faktor mengapa tidak ditemukannya gigi yang ditambal sehingga skor filling responden yang didapatkan nol. Status karies berada pada kategori sedang dapat dipengaruhi oleh status sosial ekonomi. Mayoritas pekerjaan orang tua dari responden penelitian adalah buruh bangunan diikuti oleh urutan kedua yaitu petani.Berdasarkan data tersebut menunjukkan rata-rata siswa-siswi SMP Negeri 4 Touluan berasal dari keluarga dengan status sosial ekonomi menengah kebawah. Sebuah penelitian oleh Källestål dan Wall di Swedia menunjukan adanya hubungan status sosial ekonomi dengan kejadian karies gigi pada anak 12-14 tahun yaitu anak yang berasal dari golongan sosial ekonomi yang rendah memliki resiko karies gigi yang lebih tinggi dibandingkan dengan anak yang berasal dari keluarga golongan sosial ekonomi menengah dan tinggi, sehingga dapat dikatakan peran pendidikan orang tua tentang kebersihan gigi dan mulut dapat berpengaruh terhadap status karies pada anak. Orang tua dengan pengetahuan kesehatan gigi dan mulut yang baik juga memiliki anak dengan status karies yang rendah dibandingkan dengan orang tua dengan pengetahuan kesehatan gigi dan mulut yang kurang baik. ${ }^{10}$ SMP Negeri 4 Touluaan tidak memiliki sarana UKGS. Menurut penelitian yang dilakukan oleh Karmawati di Cilandak, Jakarta, terdapat perbedaan resiko terjadinya karies antara sekolah yang memiliki sarana UKGS dan sekolah yang tidak memiliki sarana UKGS. Sekolah yang memiliki sarana UKGS memiliki angka kejadian karies yang cenderung lebih rendah dibandingkan sekolah yang tidak memiliki UKGS. ${ }^{11}$ Ada tidaknya UKGS di Sekolah ini dapat berpengaruh pada indeks DMF-T yang didapatkan, karena rendahnya kesadaran para siswa-siswi akan pentingnya kesehatan gigi dan mulut.Menurut pengamatan peneliti, anak-anak SMP Negeri 4 Touluan memiliki kebiasaan jajan saat jam istirahat makan. Jajanan dengan mudah didapatkan oleh anak-anak di depan sekolah, baik kaki lima maupun warung dekat sekolah. Konsumsi jajanan yang tidak terpantau berpengaruh pada peningkatan terjadinya karies. Hasil penelitian dari Worotitjan di desa Kiawa kecamatan Kawangkoan Utara. Pola makanan karbohidrat tertinggi pada anakanak ialah snack yang biasanya dikonsumsi dengan frekuensi waktu 2-3 kali sehari. Penelitian tersebut juga mendapatkan Skor indeks DMF-T dari responden sebesar 3,71. ${ }^{12}$ Hampir sama dengan angka yang peneliti dapatkan dari hasil pemeriksaan DMF-T murid SMP Negeri 4 Touluaan. Ditinjau berdasarkan jenis kelamin hasil pemeriksaan DMF-T yang di dapatkan ialah laki-laki 3,82 dan perempuan 3,15. Kedua-duanya tergolong dalam kategori sedang menurut kriteria WHO. Hasil 
penelitian dari Mangkey di Tomohon menunjukkan laki-laki memiliki status karies yang lebih tinggi dibandingkan perempuan yaitu sebesar 2,29 (laki-laki) dan 2,23 (perempuan). ${ }^{13}$ Hasil ini berbeda dengan hasil penelitian yang dilakukan oleh Pontonuwu yang mendapatkan skor indeks DMF-T pada anak perempuan lebih tinggi dibandingkan pada anak laki-laki yaitu sebesar $\quad 3,4 \quad$ (laki-laki) dan 3,6 (perempuan). ${ }^{8}$ Menurut RISKESDAS tahun 2013 indeks DMF-T berdasarkan jenis kelamin adalah 4,1 untuk laki-laki dan 4,9 untuk perempuan. Indeks DMF-T pada perempuan tergolong tinggi, sedangkan laki-laki tergolong dalam kategori sedang. ${ }^{6}$ Pada penelitian ini status karies pada lakilaki lebih tinggi dibandingkan dengan perempuan, hal ini mungkin terjadi karena responden laki-laki lebih banyak dibandingkan responden perempuan. Berdasarkan usia yang terbagi atas 3 golongan usia yaitu 12, 13, dan 14. Hasil DMF-T didapatkan ialah usia 12 tahun 3,1, usia 13 tahun 4,08, dan usia 14 tahun 3,33. Skor DMF-T tertinggi didapatkan oleh usia 13 tahun. Hasil ini berbeda dengan hasil yang di dapatkan oleh Mangkey dalam penelitiannnya di Tomohon. Skor tertinggi pada penilitian tersebut didapatkan oleh golongan usia 12 tahun sebesar 2,40 disusul oleh usia 14 tahun yaitu sebesar 2,22 dan usia 13 tahun 2,17. ${ }^{13}$ Usia yang lebih dewasa memiliki pengetahuan yang lebih baik tentang pemeliharaan kesehatan gigi dan mulut yang baik. Kekurangan pengetahuan akan cara memelihara kesehatan gigi dan mulut yang baik dapat menjadi salah satu faktor yang memengaruhi indeks DMF-T yang didapatkan. Menyikat gigi dengan cara yang benar merupakan salah satu upaya pemeliharaan kesehatan gigi dan mulut yang baik. Hasil penelitian Pantow di manado menunjukkan bahwa ada pengaruh yang nampak dari penyuluhan cara menyikat gigi terhadap penurunan indeks plak. ${ }^{14}$ Menurut Kidd dalam bukunya yang berjudul Dasar-dasar karies, plak merupakan lengketan bakteri beserta produk-produknya. ${ }^{1}$ Salah satu bakteri yang menempel dalam plak ialah Streptococcus mutans yang merupakan bakteri yang bersifat kariogenik, yang bila akumulasi plak pada gigi tinggi maka besar pula kemungkinan gigi yang berlubang. Penelitian ini menunjukan angka skor indeks DMF-T sebesar 3,52 yang tergolong dalam kategori sedang.

\section{SIMPULAN}

Status karies pada murid SMP Negeri 4 Touluaan berdasarkan kelompok usia, jenis kelamin, dan juga secara keseluruhan berada pada kategori sedang menurut kriteria WHO. Rata-rata indeks DMF-T murid SMP Negeri 4 Touluaan ialah 3,52.

\section{SARAN}

Pemerintah setempat perlu untuk menghadirkan tenaga medis yang berkompeten dalam bidang kesehatan gigi dan mulut, agar penanggulangan kuratif dapat diberikan pada masyarakat yang membutuhkan.

Diharapkan juga penyuluhan kesehatan gigi dan mulut dapat diberikan lebih lanjut kepada masyarakat Minahasa Tenggara. Sekolah perlu untuk melakukan upaya peningkatan kesehatan gigi dan mulut bagi para murid. Hal ini dapat dilakukan dengan cara pengadaan UKGS dan dengan penyuluhan cara menyikat gigi yang baik dan benar.

Perlu diadakannya penelitian yang lebih lanjut dibidang kesehatan gigi dan mulut di kabupaten Minahasa Tenggara.

\section{DAFTAR PUSTAKA}

1. Kidd E, Bechal S. Dasar-dasar karies: penyakit dan penanggunalangannya, Jakarta: EGC; p.1-15.

2. Warni L. Hubungan perilaku murid SD kelas V dan VI pada kesehatan gigi dan mulut terhadap status karies gigi di wilayah Kecamatan Delitua Kabupaten Deli Serdang tahun 2009. [serial online] 2009 [cited April 2013].

3. Suwelo IS. Karies Gigi Pada Anak dengan Berbagai Faktor Etiologi. Jakarta: EGC, 1992.

4. World Health Organization. Oral health 
surveys basic methods 5th ed. 2013 [serial online: cited 2014 March].

5. Petersen PE. The world oral health report 2003. Continuous improvement of oral health in the $21^{\text {st }}$ century - the approach of the WHO Global Oral Health Programme. Geneva: World Health Organization, 2003.

6. Badan Penelitian dan Pengembangan Kesehatan. Riset kesehatan dasar. Jakarta: Departemen Kesehatan Republik Indonesia; 2013. p. 118.

7. Cypriano S, Sousa M, Wada S. Evaluation of simplified DMF-T indices in epidemiological surveys of dental caries. [cited april 2013]; Rev Saude Publica [serial online] 2005;39(2).

8. Pontonuwu J. Gambaran status karies anak sekolah dasar di kelurahan Kinilow 1 kecamatan Tomohon Utara [Skripsi]. Manado: Universitas Sam Ratulangi; 2013.

9. Kementerian Kesehatan Republik Indonesia. Rekapitulasi puskesmas kabupaten Minahasa Tenggara keadaan 31 Desember 2013. [serial online] 2013

10.Källestål C, Wall S. Socio-economic effect on caries, incidence data among Swedish 12-14 years old. Community Dentistry and Oral Epidemiology. 2002;30(2):108-14.

11.Karmawati I A, Tauchid S N, Harahap N N. Perbedaan resiko terjadinya karies baru pada anak usia 12 tahun murid SD UKGS dan SD non UKGS di wilayah kecamatan Cilandak Jakarta Selatan [Skripsi]. Jakarta: Poltekes Kemenkes Jakarta I; 2011.

12. Worotitjan I. Pengalaman karies gigi serta pola makan dan minum pada anak sekolah dasar di desa Kiawa kecamatan Kawangkoan Utara [Skripsi]. Manado: Universitas Sam Ratulangi; 2013.

13.Mangkey E. Gambaran status karies pada siswa SMP Negeri 1 Tomohon [Skripsi]. Manado: Universitas Sam Ratulangi; 2015.

14.Pantow CB. Pengaruh penyuluhan cara menyikat gigi terhadap penurunan indeks plak gigi pada siswa sd inpres Lapangan [Skripsi]. Manado: Universitas Sam Ratulangi; 2014. 